\title{
Covid-19 makes the future of UK clinical research uncertain
}

The pandemic has halted many clinical trials as focus shifts to covid-19, Gareth lacobucci finds

\author{
Gareth lacobucci
}

The BMJ

On 7 April, the leading UK charity Cancer Research UK announced with "great regret" that it had decided to cut its funding for research by $£ 44 \mathrm{~m}$ ( $€ 50.3 \mathrm{~m}$; $\$ 54.4 \mathrm{~m}$ ) this year, in response to huge fundraising shortfalls caused by the covid-19 pandemic.

The charity, which funds about half of all cancer research conducted in the UK, said that it had been forced to reduce funding for existing research grants and institutes by as much as $10 \%$ and the funding for its national network of researchers centres by around $20 \%$. "These cuts are substantial and will set back the cancer research effort within the UK, potentially for many years," it warned.

\section{Studies discontinued}

It's not just cancer that's being affected by the pandemic but the whole of medical research. William van't Hoff, chief executive of the UK government funded National Institute for Healthcare Research (NIHR) - the largest national clinical research funder in Europe-says that almost $90 \%$ of its non-commercial research has been paused because of the pandemic, although over half of its commercial research is still ongoing.

He tells The BMJ, "We absolutely recognise the impact that this [pausing of studies] has had for patients, but also for researchers who have been severely affected. I'm sure that in the short term they will understand this, but in the medium term we want to be ready to get going again."

Van’t Hoff says that, as far as possible, NIHR will look to extend research contracts and have "an open mind" on whether it will continue to fund additional research costs beyond existing schedules. But he acknowledges, "Some research, very sadly, will not continue. It may be expired, the situation may have changed, the science may have moved. That's regrettable, but there is a willingness to do our best to consider what is feasible."

\section{Fundraising hole}

Medical research charities, most of which do not benefit from endowments or government grants, are undoubtedly taking the most severe hit from the covid-19 pandemic.

In an open letter ${ }^{1}$ to its researchers, Cancer Research UK said that a huge drop in donations-resulting from shop closures, cancellations of mass fundraising events, and legacy reductions in the wake of the covid-19 crisis-had left a $£ 120 \mathrm{~m}$ hole in its income from fundraising (box 1). The charity has postponed any new funding commitments while the pandemic is ongoing, meaning that no new research projects will be funded for "at least the first half of this year."

\section{Box 1: Charity case study-Cancer Research UK}

lain Foulkes, executive director of research and innovation at Cancer Research UK, tells The BMJ that the combination of its charity shops being closed and the cancellation of Race 4 Life, its biggest mass participation event, is costing the charity " $£ 15 \mathrm{~m}-£ 20 \mathrm{~m}$ a month" during the pandemic. These elements alone mean that the charity is estimating a loss in the region of about $£ 120 \mathrm{~m}$ this year.

And Foulkes predicts that this is likely to rise when the expected downturn in legacy donations from the public is factored in-often donated in the form of stocks and shares, cash, or sale of houses. He explains, "We're one of the biggest charities in the country and we carry reserves, but only between three and four months, and we're already starting to have to draw on those.

"We hope it's a one-off. But we're all in uncharted territory, so we will have to think about what else we may need to do in the future if this carries on."

Many other charities are facing similar struggles: Action Medical Research, the Motor Neurone Disease Association, and the Alzheimer's Society are among those that have launched emergency fundraising appeals to try to compensate for losses in fundraising income.

\section{Five years lost}

Charlie Swanton, Cancer Research UK's chief clinician, who is a group leader at the Francis Crick Institute and professor of 
oncology at University College London Hospitals, tells The $B M J$ that his research on cancer is now on hold because of covid-19.

Swanton's research laboratory looks at how cancers evolve and develop drug resistance. Four parallel studies that his team were conducting are now on hold, including the large national Tracer $\mathrm{X}$ trial, a 10 year programme tracking the standard of lung cancer care for patients in a hospital setting, with patient follow-up at five years.

"In a worst case scenario we've potentially lost five years," he tells The BMJ. "I'm very concerned that a substantial part of the study will have to be repeated to be able to get to the original sample size that we had planned."

His team's experience is not uncommon across the clinical research sector. He says, "All colleagues that interface with the clinical environment are going to be very badly affected by this, and their research work is going to be hindered. It's unavoidable, and we understand why this is happening.

"But it is terribly sad from many angles to think that progress in cancer research is going to be severely impaired as a result of this crisis. And that's just cancer research; you can imagine that the same would hold true for any area of medicine."

\section{Shifting focus}

In the meantime, the UK's clinical research focus has pivoted sharply towards covid-19 (box 2). UK Research and Innovation, the national funding agency for science and research in the UK, has moved to refocus its activities and to streamline applications for new research, including publishing guidance for researchers who currently hold grants, on how they might repurpose their funds for covid-19. ${ }^{2}$

\section{Box 2: How the research world has shifted its focus to covid-19}

Much of the UK's research energy is now being channelled into covid-19, with a focus on studies that will have the biggest impact in the shortest time. Earlier this month the four chief medical officers and NHS England's national medical director wrote a joint letter to every NHS trust in the country, asking them to enrol patients into nationally prioritised covid-19 clinical trials. Their letter

highlights three key interventional studies:

- PRINCIPLE, a platform trial of interventions against covid-19 in older people;

- RECOVERY, a trial to evaluate whether existing or new drugs can help patients admitted to hospital with confirmed covid-19 (see RECOVERY Trial: the UK Covid-19 Study Resetting Expectations for Clinical Trials (BMJ 2020;369:m1626, doi:10.1136/bmj.m1626)); and

- REMAP-CAP, a platform trial for severely ill patients with covid-19.

The letter advises clinicians not to use off-licence treatments outside a trial. "Use of treatments outside of a trial, where participation was possible, is a wasted opportunity to create information that will benefit others," it says. William van't Hoff, chief executive of the National Institute for Healthcare Research, tells The BMJ that the institute is overseeing around 25 covid-19 studies in total, ${ }^{4}$ selected from more than 360 submitted so far for assessment and has already supported the recruitment of over 11000 patients. "We're prioritising studies that are ready to go, that are likely to deliver results that are generalisable to the NHS in short order in high time," he says.

On a global scale, a trial tracker service ${ }^{5}$ set up by the advocacy group TranspariMED estimates that more than 1000 clinical trials of potential covid-19 treatments and interventions have been launched worldwide to date (28 April). The non-profit Anticancer Fund has produced an open access online database listing all of the interventional clinical trials ongoing in covid-19. ${ }^{6}$ As of 28 April it had identified 891 clinical trials registered to fight covid-19 around the world, with 253 drugs involved.
The Wellcome Trust (which, unlike many research charities, is funded from endowments) has committed $\$ 50 \mathrm{~m}$ ( $£ 40.5 \mathrm{~m}$; $€ 46.4 \mathrm{~m}$ ) to set up a joint covid-19 Therapeutics Accelerator initiative with the Gates Foundation and Mastercard, ${ }^{3}$ to coordinate research efforts and remove barriers to drug development.

Most researchers at Swanton's lab have been redeployed at a new covid-19 testing lab, which he helped set up at the Crick Institute to help boost capacity to test NHS staff for coronavirus. It's here that he says his focus will be until his other work can recommence.

"To cut a long story short, my research life has been put on hold," explains Swanton. "Getting over this crisis is our most critical and important goal right now. That's why we've repurposed the laboratory, and we are working with many others at the Crick to focus purely on supporting and helping the NHS."

Van't Hoff says that, like the whole of society, the covid-19 crisis has forced the whole research sector to "rethink the way we do things," which he believes is no mean feat. "It's incredibly impressive to me how joined up the health system and the health research organisations have been to try and speed up the access, volume, and delivery of research to help patients, the country, and the NHS," he says.

Swanton voices similar sentiments, but he's also anxious about what the future holds. "The coronavirus question dominates everything, and the length of time this goes on will directly influence the number of obstacles that exist to set the lab up again when we all come back eventually," he says. "If this goes on for six months or more, we could be looking at a very different world from a research perspective when it comes to the financial resource to keep Britain's research and development engine going. That is a big concern to us."

Competing interests: I have read and understood BMJ policy on declaration of interests and have no relevant interests to declare.

Provenance and peer review: Commissioned; not externally peer reviewed.

bmj.com Feature: RECOVERY Trial: the UK covid-19 study resetting expectations for clinical trials (BMJ 2020;369:m1626, doi:10.1136/bmj.m1626)

1 Foulkes I, Vousden K, Swanton C. COVID-19: Open letter to cancer researchers. Cancer Research UK. 6 Apr 2020. https://www.cancerresearchuk.org/funding-for-researchers/ research-features/2020-04-06-covid-19-open-letter-to-cancer-researchers.

2 Walport M. Open letter to the research and innovation community-UK. UK Research and Innovation. 30 Mar 2020. https://www.ukri.org/news/open-letter-to-the-research-andinnovation-community/.

3 COVID-19 Therapeutics Accelerator. Advancing research into accessible coronavirus treatments. https://www.therapeuticsaccelerator.org/.

4 National Institute for Health Research. COVID-19 studies. https://www.nihr.ac.uk/covidstudies/.

5 Bruckner T. All COVID-19 clinical trials at a glance. TranspariMED. 9 Apr 2020. https:// www.transparimed.org/single-post/2020/03/27/COVID-19-clinical-trials-information-sources.

6 Anticancer Fund. More than 200 trials to fight COVID-19 worldwide. 7 Apr 2020. https:// www.anticancerfund.org/en/more-200-trials-fight-covid-19-worldwide.

Published by the BMJ Publishing Group Limited. For permission to use (where not already granted under a licence) please go to http://group.bmj.com/group/rights-licensing/ permissions 